\title{
Pendekatan penelitian pendidikan: Tinjauan dari perspektif filsafat ilmu
}

\section{Miftakhuddin \\ Universitas Negeri Yogyakarta, Indonesia}

\author{
A R T I C L E I N F O \\ Article history: \\ Received 01 Januari 2021 \\ Accepted 12 April 2021 \\ Available online 30 Juni \\ 2021 \\ Kata Kunci: \\ Pendekatan penelitian \\ Penelitian pendidikan \\ Filsafat ilmu \\ Keywords: \\ Research approach \\ Educationl approach \\ Philosophy of science
}

\begin{abstract}
A B S T R A K
Pada dasarnya, pendekatan mana yang hendak dipakai oleh peneliti bergantung pada karakteristik masalah, jenis data, perspektif peneliti, dan tujuan dari dilakukannya penelitian tersebut. Oleh karena itu, diperlukan pemahaman yang kokoh untuk menentukan apakah suatu permasalahan baiknya diteliti denga pendekatan kuantitatif, ataukan kualitatif. Guna mempermudah, barangkali bisa melihat pembagian menurut McMillan \& Schumacher (2001). Mengingat bahwa penelitian dalam bidang pendidikan (baik pendidikan dasar, menengah, maupun tinggi) termasuk dalam lingkup sosial, maka umumnya induk penelitiannya adalah penelitian dasar (basic research), yang nantinya akan sangat bermanfaat untuk penelitian terapan (applied research). Sedangkan pendeakatan yang sebaiknya dipakai adalah bergantung kepada karakteristik data, masalah, sudut pandang penelitian, dan tujuan dilakukannya penelitian itu.
\end{abstract}

A B S T R A C T

Basically, which approach a researcher wants to use depends on the characteristics of the problem, the type of data, the researcher's perspective, and the purpose of the research. Therefore, a solid understanding is needed to determine whether a problem should be investigated using a quantitative or qualitative approach. To make things easier, maybe you can look at the division according to McMillan \& Schumacher (2001). Given that research in the field of education (both primary, secondary, and higher education) is included in the social sphere, generally the main research is basic research, which will be very useful for applied research. While the approach that should be used depends on the characteristics of the data, the problem, the research point of view, and the purpose of the research.

Copyright (c) osf.io. All rights reserved.

\section{PENDAHULUAN}

Rasa ingin tahu manusia hanya akan terpuaskan dengan pengetahuan, baik secara logika, etika, mupun estetika. Pengetahuan logika memisahkan antara benar dan salah, etika memisahkan baik dan buruk, sedangkan estetika memisahkan indah dan tidak indah. Sayangnya untuk mendapatkan pengetahuan itu, sarana paling utama adalah indera manusia, yang serba terbatas. Sehingga pengetahuan yang diperoleh sepenuhnya melalui indera belum dapat dikatakan sebagai kebenaran atau pengetahuan ilmiah (ilmu), terutama pengetahuan logika, yang umum dipakai untuk mendeteksi kebenaran.

Sejarah perkembangan berpikir manusia, menunjukkan upaya menemukan kebenaran selalu diekspresikan ke dalam dua cara, yaitu pendekatan non-ilmiah, dan pendekatan ilmiah. Pendekatan non-ilmiah menggunakan pola pikir sederhana, sedangkan pendekatan ilmiah menggunakan pola pikir kompleks dan menuntut cara yang logis, sistematis, terencana, dan mengikuti konsep ilmiah (Masyhud, 2014). 
Pendekatan non ilmiah, meliputi: a) akal sehat (common sense), yang merupakan bagan konseptual yang memuaskan untuk penggunaan praktis bagi kemanusiaan (Kerlinger, 1981). b) kegigihan/keuletan, yang merupakan ekspresi mempertahankan kebenaran yang sebelumnya telah diperoleh. c) prasangka dan apriori, yang harus sesuai nalar. d) pengalaman empiris. e) trial and error. f) otoritas, dengan bersandar kepada pendapat para ahli atau orang tertentu yang berwenang dan diberi kekuasaan. g) menggunakan logika, baik deduktif mapun induktif (Ary et al., 2010; Masyhud, 2014). Namun demikian, dewasa ini (terutama sesudah lewat Abad Kegelapan (Dark Age) di Eropa), upaya untuk mendapatkan kebenaran diraih dengan menempuh jalan ilmiah (Miftakhuddin, 2020).

Ada dua teori kebenaran pengetahuan, yaitu teori koherensi dan korespondensi. Teori koherensi beranggapan bahwa suatu pernyataan dikatakan benar apabila sesuai dan tidak bertentangan dengan pernyataan sebelumnya. Aturan yang dipakai adalah logika berpikir. Sementara teori korenspondensi

berasumsi bahwa sebuah pernyataan dipandang benar apabila sesuai dengan kenyataan (fakta atau realita) saat ini. Oleh karena itu, demi menemukan kebenaran yang logis dan didukung oleh fakta saat ini, maka harus dilakukan penelitian terlebih dahulu. Inilah hakikat penelitian sebagai kegiatan ilmiah atau sebagai proses the acquisition of knowledge (Depdiknas, 2008). Penelitian adalah penelaahan terkendali yang mengandung dua hal pokok yaitu logika berpikir dan data/informasi yang dikumpulkan secara empiris (Schreiber \& Asner-Self, 2011; Sudjana, 2001).

Awalnya, untuk menemukan kebenaran dengan jalan penelitian, dipakai pendekatan kualitatif dan kuantitatif, tapi kini telah berkembang pula mix-method. Pendekatan kualitatif menggunakan logika berpikir induktif (oleh karenanya menggunakan sarana statistika), bersetting natural, menggunakan purposive sampling, dan menggunakan interpretasi berulang. Tujuan pendekatan kualitatif adalah untuk menemukan local meaning yang mendalam dan menghasilkan hipotesis. Kebalikannya, pendekatan kuantitatif menggunakan logika berpikir deduktif (oleh karenanya menggunakan sarana berpikir matematika), ber-setting eksperimental, menggunakan probability sampling, dan menggunakan pemodelan untuk analisisnya. Tujuan pendekatan kuantitatif adalah membuat generalisasi dan menguji hipotesis. Sedangkan pendekatan mix-method, menggabungkan kedua pendekatan tersebut. Mix-method hanya akan dipakai jika suatu persoalan tidak cukup mampu terjawab hanya dengan memakai satu pendekatan saja. Demikianlah ilmu sebagai pengetahuan ilmiah dapat diakui sebagai kebenaran yang sahih dan ajek.

Berangkat dari tiga pendekatan di atas, metodologi ilmiah dalam menemukan kebenaran kemudian diterjemahkan ke dalam berbagai macam penelitian, yang umumnya dikategorikan menurut fungsi dan rumpun keilmuan tertentu. Ilmu-ilmu dasar, baik bidang sosial maupun eksakta, dikembangkan melalui penelitian dasar. Dalam ilmu-ilmu sosial, contohnya, hasil penelitian akan menghasilkan ilmu-ilmu sosial yang bisa saja menjadi rujukan bagi ilmu pendidikan, seperti antropologi, sosiologi, ekonomi, sejarah, politik, dan lain-lain (Miftakhuddin et al., 2019). Sedangkan ilmu-ilmu terapan (kedokteran, teknologi,

dan pendidikan) dikembangkan melalui penelitian terapan, dengan memanfaatkan ilmu dasar. Penelitian dasar (basic research) adalah penelitian yang dilakukan dengan tujuan mengembangkan teori-teori ilmiah atau prinsip-prinsip mendasar dan umum dari bidang ilmu yang bersangkutan. Lebih dari itu, menurut (Sukmadinata, 2005), penelitian dasar juga dapat digunakan untuk meningkatkan pencarian dan metodologi ilmiah. Sedangkan penelitian terapan (applied research) ditujukan untuk menemukan teori-teori atau prinsip-prinsip baru dan menguji manfaat teori atau prinsip sebelumnya secara mendasar dan umum dari masalah yang 
dikaji, sehingga dapat memecahkan/mengatasi suatu masalah untuk kepentingan manusia (Sukardi, 2003). Maka dari itu penelitian terapan membutuhakn hasil penelitian dasar, hasilnya pun tidak perlu sebagai penemuan baru, melainkan bentuk aplikasi baru dari penelitian yang sudah ada. Salah satu contohnya adalah penelitian Murwonugroho \& Miftakhuddin (2020) yang membahas seni pada relief candi peninggalan masa lampau Terlepas dari dua jenis penelitian itu, menurut Depdiknas (2008) ada juga penelitian evaluatif (evaluation research) yang bertujuan menilai manfaat, kegunaan, atau kelayakan suatu kegiatan/program tertentu.

Kemudian muncul pertanyaan; "jika pengetahuan akan kebenaran dalam dunia pendidikan, sebaiknya menggunaan pendekatan penelitian yang mana?". Jawaban atas pertanyaan itu akan diperoleh manakala pertanyaan apa tujuan dari penelitian itu sudah terjawab. Sebab menurut tujuannya, penelitian dapat dibedakan menjadi: penelitian eksploratif, yang bertujuan menggali sebab-sebab terjadinya fenomena; penelitian verifikatif, yang bertujuan menguji kebenaran dari hasil penelitian terdahulu; dan penelitian kebijakan, yang bertujuan untuk merumuskan suatu peraturan (Gall et al., 2003; Masyhud, 2014).

\section{HASIL DAN PEMBAHASAN}

Sekurang-kurangnya ada empat tema populer dalam penelitian pendidikan. Keempatnya ialah: institutional behaviour, teacher behaviour, student behaviour, dan empowerment behaviour. Institutional behavior adalah tema yang mengulas tentang perilaku-perilaku institusi pendidikan dalam menaungi penyelenggaraan

pendikan. Teacher behavior adalah tema yang mengulas tentang perilaku-perilaku guru dalam menjalankan pembelajaran dalam suatu institusi pendidikan, baik pendidikan formal, informal, maupun non-formal. Baik dalam hal merencanakan pembelajaran, melaksanakan pembelajaran maupun dalam mengevaluasi pembelajaran. Salah satu tujuan dalam pelaksanaan penelitilan dengan tema ini adalah untuk menemukan kelemahan-kelemahan suatu metode pembelajaran, kemudian mengusulkan metode baru sebagai alternatif penyelesaian masalah instruksional. Sebagai contohnya ialah penelitian (Khoiron et al., 2020) Student behavior adalah tema yang mengulas tentang perilaku siswa dan segala dinamika yang menyertainya. Tema ini adalah tema yang paling populer dalam riset pendidikan di antara 3 tema yang lain. Sedangkan empowerment behaviour adalah tema yang mengulas tentang sarana dan prasarana yang ada, dalam menunjang keberlangsungan pendidikan.

Tema-tema di atas adalah penentu utama tentang pendekatan penelitian mana yang akan dipakai oleh peneliti. Tema-tema tersebut akan membuat peneliti mengidentifikasi karakteristik masalah yang hendak diteliti, baru kemudian menyiapkan perspektif penelitian. Praktis, pendekatan penelitian mana yang hendak dipakai bukan bergantung pada keinginan peneliti, melainkan bergantung pada karakteristik masalah dan jenis data dalam penelitiannya. Pada penelitian sejarah, misalnya, yang mau tidak mau harus menggunakan pendekatan kualitatif karena sifat masalah dan bentuk datanya yang sedemikian rupa. Sebuah historiogafi dibangun atas data kualittatif-deskriptif yang biasanya memang bersifat tekstual (Miftakhuddin, 2019). Kecuali pada fase kritik sumber, analisis kuantitatif bisa saja dilakukan untuk mengkonfirmasi validitas informasi manakala ditemukan data yang meragukan, baik secara internal (keterpercayaan sumber) maupun eksternal (kualitas sumber)

Hanya saja, jika bentuk datanya deskriptif umumnya memakai pendekatan kualitatif, sedangkan jika bentuk datanya numerik (hasil pengukuran variabel), umumnya dipakai pendekatan kuantitatif. Penelitian kuantitatif sebenarnya telah lama mendominasi tidak hanya pada penelitian eksakta, tapi juga penelitian humaniora. Prinsip-prinsip teoretis penelitian kuantitatif yang salah satunya 
adalah mengkonstruksikan pengetahuan pada prosedur eksplisit, eksak, formal dalam mendefinisikan konsep serta mengukur konsep-konsep dan variabel (Poerwandari, 1998). Namun, beberapa peneliti sosial berpendapat bahwa fenomena-fenomena sosial bisa saja angat unik, sehingga sulit dibakukan berdasarkan pengukuran tertentu, yangmana jika dipaksakan akan menghilangkan makna yang sesungguhnya

\section{Kuantitatifatau kualitatif?}

Walaupun menurut Dabbs (1982) keduanya tidak mempunyai perbedaan, namun faktanya banyak perbedaan yang cukup fundamental. Ada perbedaan diametral yang ditunjukkan oleh Miles \& Huberman (1994) dengan merujuk pada pendapat dua pakar; Kerlinger dan Campbell. Kerlinger mengatakan "there is no such thing as qualitative data. Everything is either 1 or 0". Sedangkan Campbell, mengatakan "all research ultimately has a qualitative grounding". Karena penelitian kualitatif cenderung menilai kualitas hal-hal menggunakan kata-kata, sedangkan sebagian besar penelitian kuantitatif sangat bergantung pada angka, banyak orang yang salah menganggap strategi kuantitatif lebih ilmiah daripada yang digunakan dalam penelitian kualitatif (Berg, 2004).

Pendekatan kuantitatif didasari oleh filsafat positivisme logikal (logical positivism) yang beroperasi dengan aturan-aturan ketat mengenai logika, kebenaran, hukum-hukum, dan prediksi (Watson, dalam Danim, 2002). Fokus penelitiannya diidentifikasikan sebagai proses kerja yang berlangsung secara ringkas, terbatas dan memilah-milah permasalahan menjadi bagian yang dapat diamati dan diukur atau dinyatakan dalam angka-angka (O'leary, 2004). Penelitian ini dilaksanakan untuk menjelaskan, menguji hubungan antar variabel, menentukan kausalitas dari variabel, menguji teori dan mencari generalisasi yang mempunyai nilai prediktif atau meramalkan gejala tertentu (Depdiknas, 2008).

Sedangkan penelitian kualitatif didasari oleh filsafat konstruktivisme, yang berasumsi bahwa kenyataan itu berdimensi jamak, interaktif, dan merupkakan suatu pertukaran pengalaman sosial yang diinterpretasikan oleh setiap individu (Sukmadinata, 2005). Peneliti kualitatif percaya bahwa kebenaran adalah dinamis dan dapat ditemukan hanya melalui penelaahan terhadap orang-orang melalui interaksinya dengan situasi sosial mereka (Danim, 2002; Yin, 2014). Penelitian kualitatif mengkaji perspektif partisipan dengan strategi-strategi yang bersifat interaktif dan fleksibel (Miles et al., 2014). Ia berusaha memahami fenomenafenomena sosial dari sudut pandang partisipan, dalam kondisi alamiahnya (Sugiyono, 2005).

Agar lebih jelas, dapat kiranya diamati perbedaan kapan dari salah satu pendekatan tersebut dapat dipakai menurut Depdiknas (2008) di bawah ini.

Kuantitatif

- Bila masalah yang merupakan titik tolak penelitian sudah jelas.

- Bila peneliti ingin mendapatkan informasi yang luas dari suatu populasi

- Bila ingin diketahui sejauh mana pengaruh perlakuan/ treatment terhadap subyek tertentu

- Bila peneliti ingin mendapatkan data yang akurat, berdasarkan fenomena yang empiris dan dapat diukur

- Bila peneliti ingin menguji terhadap adanya suatu keraguan tentang kebenaran pengetahuan, teori, dan produk atau kegiatan tertentu

\section{Kualitatif}

- Bila masalah penelitian belum jelas, masih remang-remang atau mungkin malah masih gelap

- Bila peneliti ingin memahami makna di balik data yang tampak

- Bila peneliti ingin memahami interaksi sosial

- Bila peneliti ingin memastikan kebenaran data

- Bila ingin meneliti tentang sejarah atau perkembangan 
Namun demikian, karena adanya beberapa persoalan yang menuntut pemecahan dan penemuan kebenaran secara simultan dan komprehensif, maka dikembangkanlah pendekatan mix-method, yangmana menurut Strauss \& Corbin (1990) pendekatan semacam ini memang layak dimunculkan. Pendekatan ini belum banyak dipakai, tapi dalam ilmu-ilmu sosial telah membuka kesempatan, utamanya dalam penelitian kebijakan pendidikan (Brannen, 1997). Pendekatan ini semacam triangulasi metode untuk melakukan penelitian, antara metode kualitatif dan metode kuantitatif (Creswell, 2012; Denzin, 1978). Ketika menjalankan mixmethod, menurut Brannen (1997) ada beberapa acuan yang harus ditaati, yakni sebagai berikut.

1. Penelitian kuantitatif sebagai fasilisator penelitian kualitatif; maksud dari acuan ini adalah:

a. Penelitian kuantitatif memberikan data latar belakang yang terukur untuk mengaitkannya dengan studi-studi skala kecil. Ini seringkali diambil dari data-data statistik atau sensus.

b. Survei kuantitatif dapat memberikan landasan bagi data kasus dar kelompokkelompok tertentu yang akan melandasi studi intensif dalam penelitian kualitatif.

2. Penelitian kualitatif sebagai fasilitator penelitian kuantitatif; berarti penelitian kualitatif berperan sebagai penunjang. Penelitian kualitatif mempunyai fungsi tertentu yaitu: sebagai sumber hipotesis yang akan diuji secara kuantitatif; sebagai pengembang dan pemandu instrumeninstrumen penelitian kuantitatif seperti kuesioner, skala dan indeks pengukuran; serta sebagai pembanding temuan-temuan kuantitatif.

3. Penelitian yang mempergunakan kedua pendekatan dengan bobot sama; kedua pendekatan dilakukan untuk saling mengisi kesenjangan yang muncul pada saat survei lapangan, analisis, atau pelaporan. Gabungan antara keduanya dapat berakhir dengan pemisahan penelitian kualitatif dan kuantitatif tetapi tetap berhubungan.

\section{SIMPULAN}

Pada dasarnya, pendekatan mana yang hendak dipakai oleh peneliti bergantung pada karakteristik masalah, jenis data, perspektif peneliti, dan tujuan dari dilakukannya penelitian tersebut. Oleh karena itu, diperlukan pemahaman yang kokoh untuk menentukan apakah suatu permasalahan baiknya diteliti denga pendekatan kuantitatif, ataukan kualitatif. Guna mempermudah, barangkali bisa melihat pembagian menurut McMillan \& Schumacher (2001) dalam tabel di bawah ini.

Tabel jenis-jenis pendekatan dan desain penelitian

\begin{tabular}{|c|c|c|c|}
\hline \multicolumn{2}{|c|}{ Kuantitatif } & \multicolumn{2}{|c|}{ Kualitatif } \\
\hline Eksperimen & Non Eksperimen & Interaktif & Non Interaktif \\
\hline $\begin{array}{l}\text { - True eksperimen } \\
\text { - Quasi eksperien } \\
\text { - Subjek tunggal }\end{array}$ & $\begin{array}{l}\text { - Deskriptif } \\
\text { - Komparatif } \\
\text { - Korelasi } \\
\text { - Survei } \\
\text { - Ex-post facto }\end{array}$ & $\begin{array}{l}\text { - Etnografi } \\
\text { - Fenomenologi } \\
\text { - Studi kasus } \\
\text { - Grounded theory } \\
\text { - Narrative inquiry }\end{array}$ & $\begin{array}{l}\text { - Analisis konsep } \\
\text { - Analisis sejarah }\end{array}$ \\
\hline
\end{tabular}

Mengingat bahwa penelitian dalam bidang pendidikan (baik pendidikan dasar, menengah, maupun tinggi) termasuk dalam lingkup sosial, maka umumnya induk penelitiannya adalah penelitian dasar (basic research), yang nantinya akan sangat bermanfaat untuk penelitian terapan (applied research). Sedangkan pendeakatan yang sebaiknya dipakai adalah bergantung kepada karakteristik data, masalah, sudut pandang penelitian, dan tujuan dilakukannya penelitian itu. 


\section{REFERENCES}

Ary, D., Jacobs, L. C., \& Sorensen, C. K. (2010). Introduction to research in education (8th ed.). Wadsworth Cengage Learning. https://doi.org/10.1017/CB09781107415324.004

Berg, B. L. (2004). Qualitative Research Method for Social Science (5th ed.). Pearson Education.

Brannen. (1997). Mixing Methods Qualitative and Quantitative Research (terj. Kurde). Pustaka Pelajar.

Creswell, J. W. (2012). Educational research: Planning, conducting, and evaluating quantitative and qualitative research (4th ed.). Pearson Education. https://doi.org/10.1017/CB09781107415324.004

Dabbs, J. M. (1982). Making things visible. In Varieties of Qualitative Research. Sage Publication.

Danim, S. (2002). Menjadi Peneliti Kualitatif. Pustaka Setia.

Denzin, N. K. (1978). The research act. McGraw-Hill.

Depdiknas. (2008). Pendekatan, Jenis, dan Metode Penelitian Pendidikan. Dirjen Peningkatan Mutu, Depdiknas.

Gall, M. D., Gall, J. P., \& Borg, W. R. (2003). Educational research: An introduction (7th ed.). Pearson Education.

Kerlinger, F. N. (1981). Foundataion of behavioral research (3rd ed.). Holt, Rinehart \& Watson.

Khoiron, M., \& Wahyuningtyas, N. (2020, February). Revitalization of Social Studies Education: A Developmental Study Based on Dick and Carey Instructional Design. In International Conference on Social Studies and Environmental Issues (ICOSSEI 2019) (pp. 37-42). Atlantis Press. https:// dx.doi.org/10.2991/assehr.k.200214.007

Masyhud, M. S. (2014). Metode penelitian pendidikan. Lembaga Pengembangan Manajemen dan Profesi Kependidikan.

McMillan, J. H., \& Schumacher, S. (2001). Research in Education. Longman.

Miftakhuddin, M. (2020). Kolonialisme: Eksploitasi dan pembangunan menuju hegemoni. Jejak Publisher. https://doi.org/10.31219/osf.io/7ms6v

Miftakhuddin, M. (2020). Historiografi Korupsi di Indonesia: Resensi Buku Korupsi dalam Silang Sejarah Indonesia. Rihlah: Jurnal Sejarah dan Kebudayaan, 7(2), 168172. https://doi.org/10.24252/rihlah.v7i2.11772

Miftakhuddin, A. M., \& Zulfiati, H. M. (2019). Misconceptions between Social Studies and Social Sciences among Pre-Service Elementary Teachers. International Journal of Education, 12(1), 16-25. https://doi.org/10.17509/ije.v12i1.17514

Miles, M. B., \& Huberman, A. M. (1994). Qualitative Analysis: An Expanded Sourcebook (2nd ed.). Sage Publication.

Miles, M. B., Huberman, A. M., \& Saldana, J. (2014). Qualitative data analysis: A methods sourcebook (3rd ed.). Sage Publication. https://doi.org/10.1080/0140528790010406 
Murwonugroho, W., \& Miftakhudin, M. (2020). Kajian Rupabheda: Tokoh-Tokoh Sri Tanjung pada Relief Candi Penataran. Panggung, 30(2). https://doi.org/http://dx.doi.org/10.26742/panggung.v30i2.953

O’leary, Z. (2004). The essential guide to doing research. Sage Publication.

Poerwandari, K. (1998). Pendekatan Kualitatif dalam Penelitian Sosial. LPSP3-UI.

Schreiber, J., \& Asner-Self, K. (2011). Educational Research. John Wiley \& Sons.

Strauss, \& Corbin. (1990). Basics of Qualitative Research. Sage Publication.

Sudjana, N. (2001). Tuntunan Penyusunan Karya Ilmiah. Sinar Baru.

Sugiyono. (2005). Memahami Penelitian Kualitatif. Alfabeta.

Sukardi. (2003). Metodologi Penelitian Pendidikan. Bumi Aksara.

Sukmadinata, N. S. (2005). Metode Penelitian Pendidikan. Remaja Rosdakarya.

Yin, R. K. (2014). Case study research: Design and methods (5th ed.). Sage Publication. 